\title{
微小領域における高速温度センシング* （研削砥石表面温度の測定波形の特性について）
}

\author{
磯 部 佳 成*1, 加 藤 泰 生*2 \\ 田戸 保*3, 香川 正 信*1

\section{High-speed Temperature Sensing in Microscopic Area (Characteristics of Measured Signals on the Grinding Wheel Surface Temperature)}

\author{
Yoshinari ISOBE, Yasuo KATOH, \\ Tamotsu TADO and Masanobu KAGAWA
}

\begin{abstract}
A new type of infrared radiation thermometer with optical fiber that has quick response time (3 $\mu \mathrm{s})$ and microscopically measurable area $(\phi 110 \mu \mathrm{m})$ was developed for thermal analysis of the grinding phenomenon. The temperature obtained depended on the heat flow rate during grinding operation and heat of oxidation of removed chips. The measured signal also indicated two parts; the base part and the impulse part. The former seemed to indicate the average temperature of grinding wheel surface, while the latter seemed to indicate the temperature of chips. The heat energy generated by oxidation was larger than the total amount of energy released by the grinding operation. When the grinding point came above the embedded optical fiber, the measured value indicated only the temperature of grinding wheel surface.
\end{abstract}

Key Words: Optical Measurement, Temperature Sensing, Microscopic Area, High-speed Sensing, Infrared Fiber Sensor, Grinding Wheel Surface, Measured Signals

\section{1. 緒言}

研削加工時の研削温度は、製品の表面品位や機械強 度などに大きく影響する11。したがって、研削温度を 測定し解析することは、製品の材質的高品位を㬰現す るために特に重要であると言える。

従来、研削温度測定で多く応用されている被加工物 を測定対象とした熱電对法 ${ }^{2), 3)}$ とは異なり、著者ら は、新しく光ファイバを用いた赤外線センサ放射温度 測定システム（以下測定システムという）を試作改良 し、これまであまり行われなかった被加工物に相対す る研削点砥石表面に着目して高速に変化する研削点砥 石表面の微小領域温度の測定を試みた。その結果、従 前の熱電対法あるいは上田ら出の結果とは異なるイン パルス部と基部を有する特徵ある波形が得られた5)。

上田らは、研削点砥石表面に混在する砥粒や切屑の 物質から放射される赤外線が赤外線センサに同時に感 知されるため、測定波形はこれらの情報を含んで示さ れると考察している。このことは、測定波形中のこれ ら放射強度を分解して各放射要素別に温度に換算する

* 平成 5 年 3 月 9 日 中国四国支部第 31 期総会講演会におい て講演, 原稿受付 平成 5 年 11 月 1 日.

*1 正員, 山口県工業技術センタ-（⑦53 山口市大字朝田湯垣 585-1).

*2 正員, 山口大学工学部（配755 宇部市常盤台 2557).

*3 正員, 宇部工業高校専門学校 (⿶755 宇部市常盤台).
ことが、きわめて困難であることを意味しており、い ままで測定波形の特性について十分に検討されていな い。したがって前報5の特徴ある波形の特性について はさらに詳細に検討する必要がある。

本報告は、この特徴的な測定波形をインパルス部、 基部に分けてそれぞれの特性を詳細に解明するため、 一つの砥粒の作用に特定した単粒研削時の温度測定さ らに被加工物材種、研削雾囲気を変化させた研削砥石 表面温度測定を行い検討した。

\section{2. 実験装置とその方法}

\section{$2 \cdot 1$ 測定システム}

本報告で用いられた測定システムを図1に示す。被 測定物から放射される赤外線は、光ファイバ（フッ化 ガラス・ステップインデックスファイバ、コア径 $\varnothing 70 \mu \mathrm{m}$ 、透過波長 $0.4 \mu \mathrm{m} \sim 4.3 \mu \mathrm{m}$ 、N.A.0.2）先端で受 光され、さらに赤外線センサ（InAs光起電力素子、 時定数 $100 \mathrm{~ns}$ 、ピーク波長 $3.2 \mu \mathrm{m}$ 、帯域波長 $1 \mu \mathrm{m} \sim$ $3.8 \mu \mathrm{m})$ に導かれたのち、電気信号に変換される。こ の電気信号は、増幅器（直流増幅器、応答速度 $3 \mu \mathrm{s}$ ） で増幅後、パーソナルコンピュータへGP-IBを介して 伝送され、記録解析される。

本测定システムは、直流增幅器の応答速度が最も遅 
く、応答速度 $3 \mu \mathrm{s}$ でこれを本測定システムの律速応答 速度とした。また測定精度は、温度較正器に用いた赤 外線映像装置（日本アビオニクス、TVS-5000、測定 精度 $0.4 \%)$ と比較した結果、指示温度の $2 \%$ あっ た。

\section{$2 \cdot 2$ 実験方法}

単粒研削時の温度測定は、測定波形のインパルス部 が研削加工時における砥石接触に起因する信号である か、あるいはノイズ信号であるかについて同定するた
め、一砥粒が発生する信号を単粒を用いて確認した。 図2は単粒研削装置の概略図、表1は加工条件を示 す。実験方法は、被加工物にS45Cを用い、乾式のワ ンパス単粒研削とした。本装置は、単粒切れ刃に導電 性セラミックスを用いアルミホイールに固定して回軽: することにより、被加工物と単粒が接触し、装置上に 電気回路が形成されるように工夫したものである。こ の電気回路の出力（以下通電出力という） と測定シス テムの測定出力の時閒的因果関係が比較検討できる。

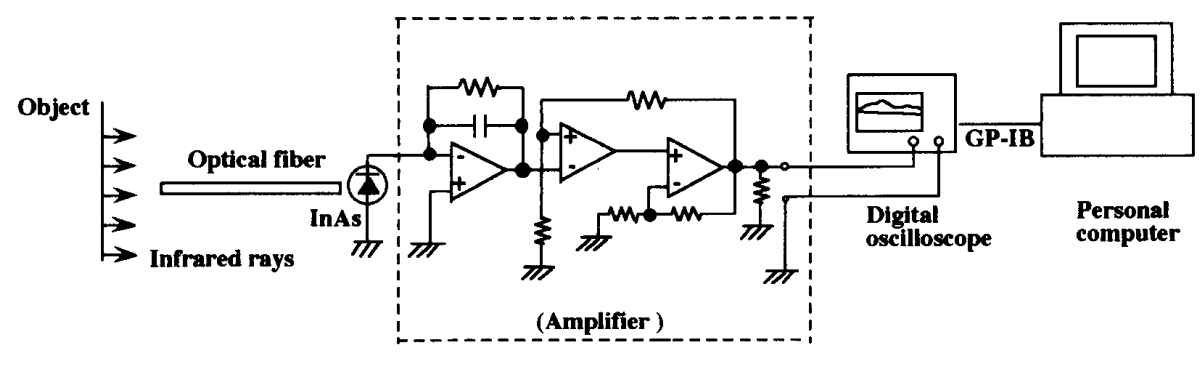

図1 測定システム概略

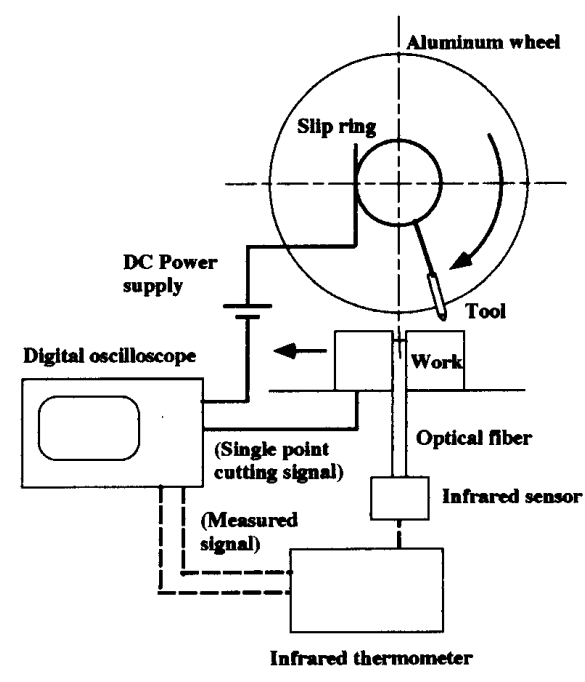

図2単粒研削装置

表1図2の加工条件

\begin{tabular}{|c|c|}
\hline Machine & $\begin{array}{c}\text { Precision surface grinding machine } \\
\text { (OKAMOTO;PSG-52AN) }\end{array}$ \\
\hline Cutting manner & $\begin{array}{c}\text { Tetragonal pyramidal single point, } \\
\text { Down cutting, } \\
\text { Dry }\end{array}$ \\
\hline Wheel & $\begin{array}{c}\text { Aluminum, } \\
\phi 200 \mathrm{~mm}\end{array}$ \\
\hline Tool & $\begin{array}{c}\mathrm{Al}_{2} \mathrm{O}_{3}-\mathrm{TiC}, \\
\text { Rake angle }-60^{\circ}\end{array}$ \\
\hline Wheel speed & $1320 \mathrm{~m} / \mathrm{min}$ \\
\hline Table speed & $15 \mathrm{~m} / \mathrm{min}$ \\
\hline Depth of cut & $20 \mu \mathrm{m}$ \\
\hline Workpiece & $\begin{array}{c}\text { S45C } ; \mathrm{Hv}(50) 616 \sim 623 \\
\text { Dimension: } \mathrm{L} 22 \times \mathrm{t} 15 \times \mathrm{W} 11 \mathrm{~mm}\end{array}$ \\
\hline
\end{tabular}

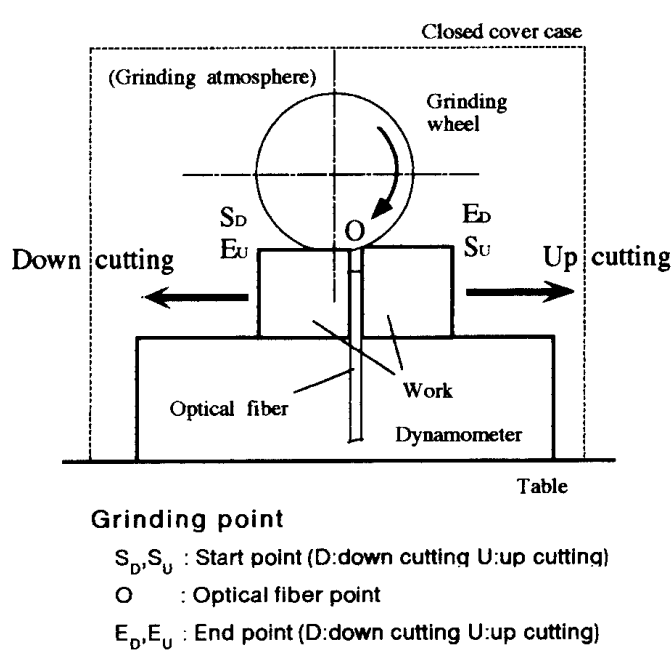

図3研削砥石表面温度測定部

表2図3の加工条件

\begin{tabular}{|c|c|}
\hline Machine & $\begin{array}{c}\text { Precision surface grinding machine } \\
\text { (OKAMOTO;PSG-52AN) }\end{array}$ \\
\hline Grinding manner & $\begin{array}{c}\text { Surface grinding, } \\
\text { Down cutting, } \\
\text { Dry }\end{array}$ \\
\hline Grinding wheel & $\begin{array}{c}\text { WA80JV } \\
\text { Dimension: } \phi 205 \times \mathrm{t} 19 \times \phi 50.8\end{array}$ \\
\hline $\begin{array}{c}\text { Grinding } \\
\text { atmosphere }\end{array}$ & $\begin{array}{c}\text { Air, } \\
\mathrm{N}_{2}\end{array}$ \\
\hline Wheel speed & $1500 \mathrm{~m} / \mathrm{min}$ \\
\hline Table speed & $15 \mathrm{~m} / \mathrm{min}$ \\
\hline Depth of cut & $20 \mu \mathrm{m}$ \\
\hline Workpiece & $\begin{array}{c}\text { SUSC } ; \mathrm{Hv}(50) 616 \sim 623 \\
\text { Dimension: } \mathrm{L} 22 \times \mathrm{t} 15 \times \mathrm{W} 11 \mathrm{~mm}\end{array}$ \\
\hline
\end{tabular}


また、研削砥石表面温度測定は、測定波形の基部相 当分を解析するため、上述と同一砥石使用時の被加工 物材種、研削雾囲気をパラメータとして、これらの変 化による測定波形の相違を確認した。図3に研削砥石 表面温度测定部概要、表2に加工条件を示す。実験方 法は、乾式のワンパス平面プランジ研削方式を採用 し、被加工物はS45C, SUS304の二種を使用した。研 削冓囲気は、研削盤上に覆いを設け、空気または不活 性ガス（窒素ガス）を充填して作りだした。なお、測 定波形と測定位置との関係については、動力計の出力 をトリガとして用いて対応させている。

各実験装置において光ファイバは、それぞれ被加工 物中央に直径 $0.8 \mathrm{~mm}$ の貫通孔を設け、マイクロメータ ヘッドを用いて被加工物表面から $100 \mu \mathrm{m}$ の位置に固 定し埋め込まれている。テーブルの移動によりこの光 ファイバ位置Oの測定可能範囲内に研削点が位置した とき、この赤外線センサにより研削熱で放射される赤 外線が測定される。测定距離 $100 \mu \mathrm{m}$ の位置で測定シ ステムの測定可能直径は $110 \mu \mathrm{m}$ となり、これは、研 削碈石WA80の平均切れ刃間隔 $390 \mu \mathrm{m}^{6) よ り 小 さ く 、 ~}$ 熱源を空間的に分離できる。また、光ファイバからみ た砥石表面速度は $24.75 \mathrm{~m} / \mathrm{s}$ で測定可能径を $4.4 \mu \mathrm{s}$ で通 過する。これは本測定システムの律速応答速度以内で ある。したがって本測定システムは、本実験の加工現 象に十分対応できる空間的時間的分解能を有する。

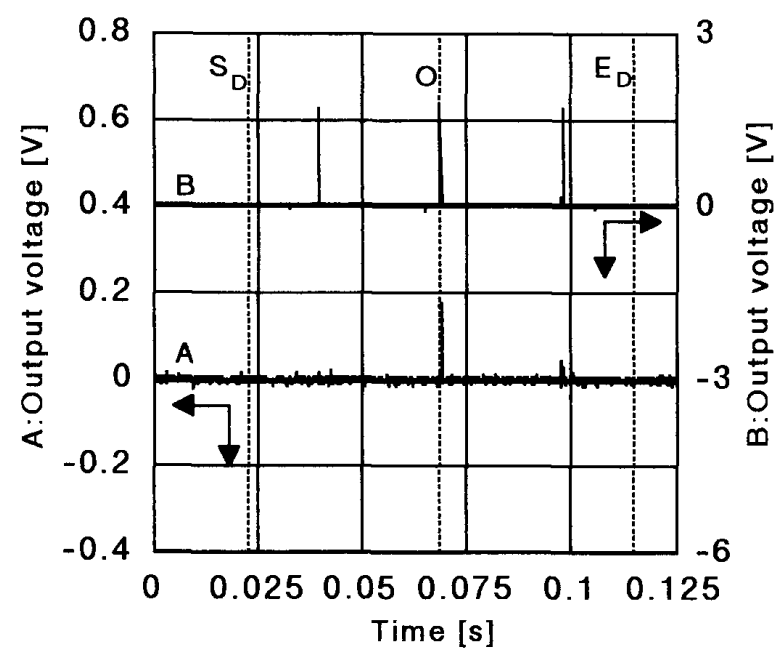

A:Measuring system B:Single point cutting system Grinding point
$S_{D}:$ Start point (Down cutting)
0 : Optical fiber point
$E_{D}$ : End point (Down cutting)

\section{3. 結果と考察}

$3 \cdot 1$ 単粒研削時の測定波形について

図4に単粒研削時の盜度測定の結果を示す。このよ うに測定システムの測定波形は、単粒研削装置の通電 出力時に示すインパルス状の出力が得られた。図中 B のインパルス状の波形は、単粒研削加工での工具と被 加工物の接触で発生した電気信号であり、工具と被加 工物の接触位置を示している。インパルス状の波形の 発生間隔は、単粒研削装置のアルミホイールの回転周 期と一致している。図中Aは、同実験において光ファ イバで単粒研削加工での工具と被加工物の接触で発生 した熱を測定した結果であるが、図中Bの測定位置O と一致したインパルス状の波形を確認することができ る。このことから単粒が被加工物と接触し、光ファイ バを通過したときの測定波形がインパルス状に発生し ていると言える。また、研削方法が下向き削りである ことから図中の○位置以降においてのみインパルス状 の波形を確認することができ、その発生間隔はアルミ ホイールの回転周期と一致している。このようにイン パルス状の測定波形は通電出力の発生間隔に対応して いることから、インパルス状の測定波形はノイズでは なく、砥粒もしくは砥粒により生成された切屑の温度 に対応した出力と考察される。さらに、上田らの研削 面表層温度測定実験 ${ }^{7}$ において、碈粒が值接作用する 加工面下で測定された測定波形には顕著なインパルス 状の波形が見られないことからも、本実験のインパル ス状の波形は切屑からの出力と考えられる。これは、 図5の研削加工後の砥粒切れ刃の観察写真において、 砥粒に付着した切屑が見られることからもインパルス

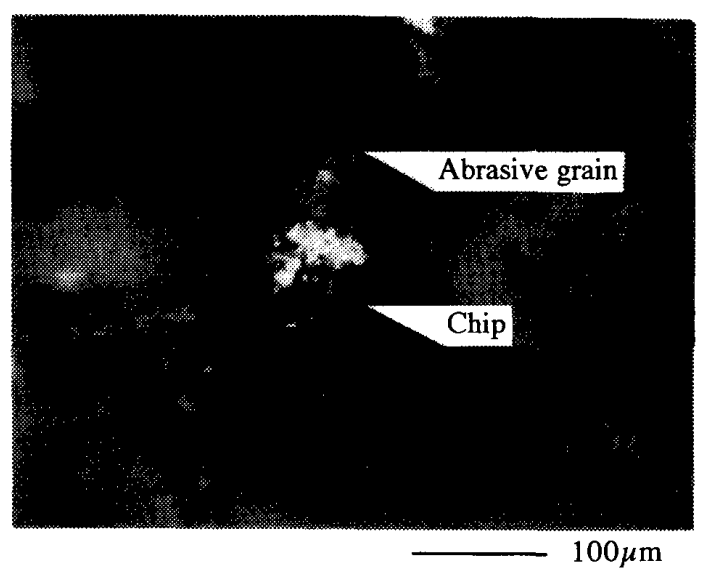

図5 砥粒に凝着した切屑

図4単粒砥石による測定波形 
状の波形は、切削時の砥粒切れ刃に切屏が凝着しなが ら排出されるため、光ファイバに切れ刃を覆い鿵す状 態で測定されたと考えられる。

\section{$3 \cdot 2$ 研削砥石表面温度測定時の被加工物材種 と測定波形について}

SUS304およびS45Cを下向き削りした場合の測定波 形を図6(a)，図6(b)にそれぞれ示す。SUS304の出力 は、光ファイバ位置O近傍より始まっているが、研削 終了点 $\mathrm{E}_{\mathrm{D}}$ に達することなくすぐに出力は終ってい る。これとは異なり S45Cの出力は、同じく光ファイ バ位置O近傍より始まり、研削終了点 $\mathrm{E}_{\mathrm{D}}$ まで徐々に增 加し最大値を示した後急激に低下し、出力は終ってい る。S45Cの測定波形は、光ファイバ位置O以後にお いてSUS304と異なり広範囲で出力している。同一加 工条件下での測定波形の相違は、明らかに被加工物材 種による影響が大きいと考えられる。本実験に使用し た被加工物の化学成分を表2に示す。ここでニッケ ル、クロム、炭素の含有量が大きく異なり、波形の相 違はこれら含有量の差異に起因すると考えられる。 S45CがSUS304より多く、強い火花の発生をみせ火花 の量、色の相違が確認されたこと、またJIS G 0566の 鋼の火花試験方法においても特に炭素含有量が火花の 発生に大きく影響することを示している8)。

3・3 研削砥石表面温度測定時の研削雾囲気と 測定波形について

前項によりS45Cの下向き削りでの測定波形は、そ

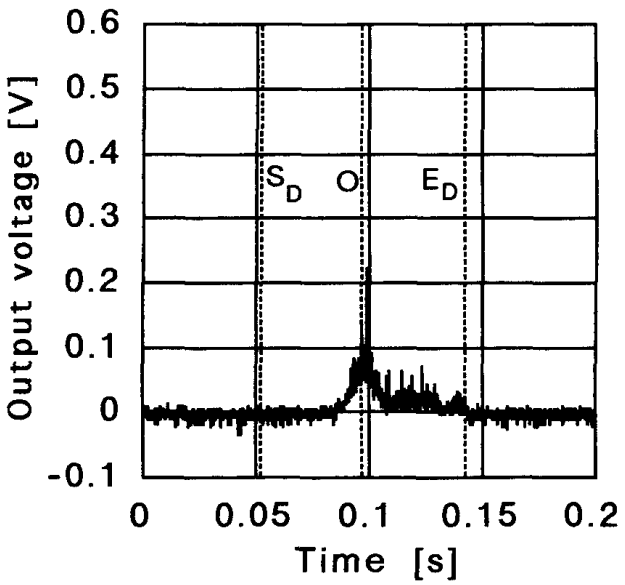

Grinding point

$S_{D}:$ Start point (Down cutting)

0 : Optical fiber point

$E_{\mathrm{D}}$ : End point (Down cutting)

図6(a) SUS304下向き削りの測定波形 (空気雾囲気)
の含有元素である炭素の影響を強く受けたことが考え られることから、次に異なる需囲気状態での測定波形 の基部相当について調べた。

\section{$3 \cdot 3 \cdot 1$ 空気急囲気}

$\mathrm{S} 45 \mathrm{C}$ 上向き削りの測定波形を図7に示す。図7の出 力は、研削開始点 $\mathrm{S}_{\mathrm{U}}$ で最大值を示したのち、徐々に低 下して研削終了点 $\mathrm{E}_{\mathrm{U}}$ で終えた。図6(b)の下向き削り と比較すると加工方向の相違により、測定波形は光フ アイバ位置Oを中心とした対称的波形を示すことがわ かる。

そして、砥石研削点に着目した目視観察 ${ }^{9}$ による と、切屑は排出直後では目立たず、ある距離を飛行 後、強く酸化発光すると述べられている。このように 下向き削り、上向き削りの光ファイバ位置Oを中心と した左右对象な測定波形は、下向き削りの場合、光フ アイバは切屑の発熱冷却の過程を順に追うこととな り、他方、上向き削りの場合、光ファイバは切屑の発 熱冷却の過程を逆に追うことになるため、このような 左右対称の波形が生じるものと考えられる。

次にS45Cを空気雾囲気で加工した場合の切屑の電

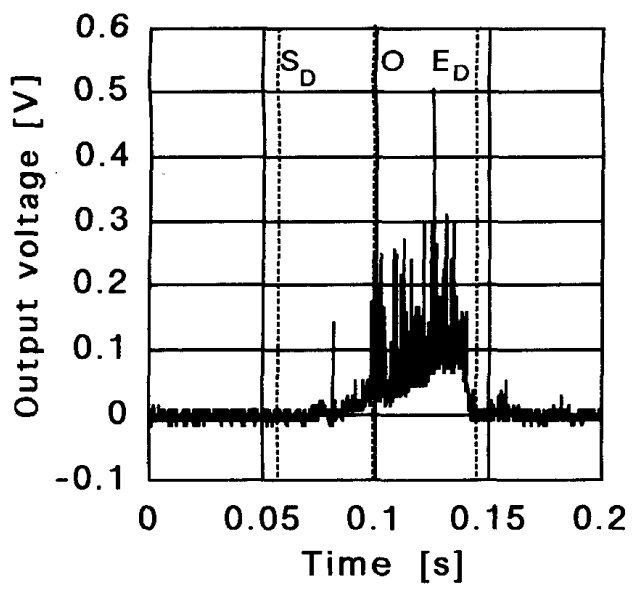

Grinding point

$S_{0}$ : Start point (Down cutting)

0 : Optical fiber point

$E_{D}$ : End point (Down cutting)

図6(b) S45C下向き削りの測定波形（空気雲曲気）

表2 被加工物の化学成分

\begin{tabular}{|c|c|c|c|c|c|c|c|}
\hline & \multicolumn{7}{|c|}{ Chemical composition (\%) } \\
\hline Metal & $\mathrm{C}$ & $\mathrm{Si}$ & $\mathrm{Mn}$ & $\mathrm{P}$ & $\mathrm{S}$ & $\mathrm{Ni}$ & $\mathrm{Cr}$ \\
\hline S45C & 0.45 & 0.23 & 0.71 & 0.05 & 0.008 & - & - \\
\hline SUS304 & 0.05 & 0.50 & 0.99 & 0.018 & $<0.001$ & 8.41 & 18.36 \\
\hline
\end{tabular}


顕(SEM)写真を図8に示す。図8には球状および流れ 型の切屑、破砕および脱落砥粒が散見される。図8の 球状切居は、切屑形状を球状に変化させるに足る溶融 温度までこの切屑温度が到達したため形成されたもの と考えられる。しかし、测定波形では温度上昇の傾向 は伺えるが、その波形に鋼の融点と考えられるような 高い值は見られなかった。したがってこの球状切屑 は、測定範囲以降の切屑飛散中にその温度上昇が進行 し、溶融温度に達したためにこのような球状が形成さ れたと推察する。

\section{$3 \cdot 3 \cdot 2$ 不活性ガス雾囲気}

切屑が球状切屑に变化しうる溶融温度とは、研削熱 による温度（砥粒が被加工物を削るとき生じる切屑と 砥粒すくい面の摩擦熱、被加工物と砥粒逃げ面の摩擦 熱そして切屑生成時のせん断すべりによる加工熱）ま たは、切屑が空中で火花を生じる酸化燃焼の発熱温度 9) などが考えられる。そこで後者すなわち切屑が空中

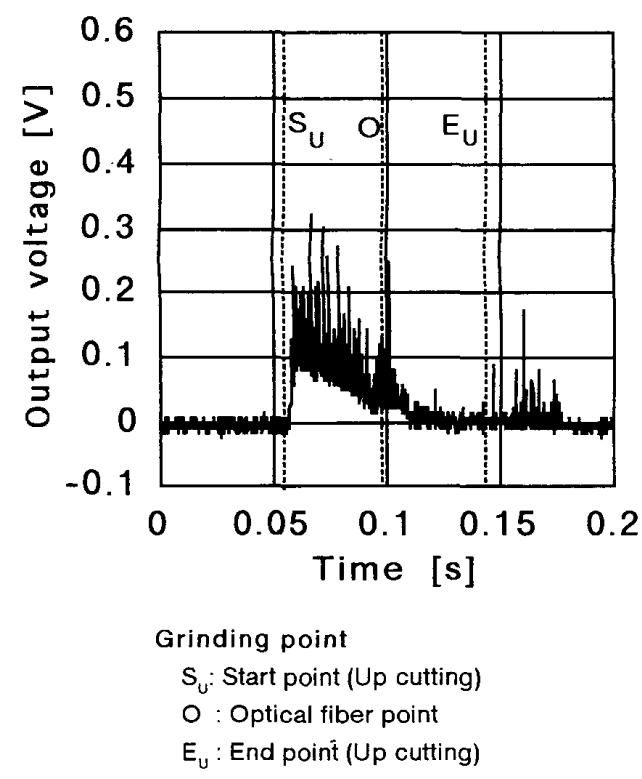

図7 S45C上向き削りの測定波形（空気雺囲気）

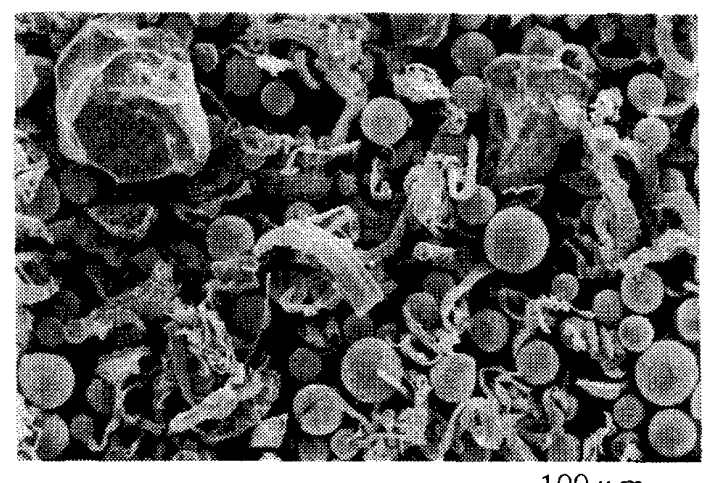

図8 S45Cの切屑（空気雾囲気）
で火花を生じる酸化燃焼の発熱温度の影響を取り除く ため、不活性ガス雾囲気中でのS45Cの研削温度の測 定を行なった。

図9は不活性ガス雾囲気中のS45C下向き削りの測定 波形例である。また、採取した切屑の電䫓(SEM)写真 を図10に示す。測定波形は、光ファイバ位置Oを出力 の最大值とする三角形状の基部とその上にインパルス 部が載っており、空気雾囲気中の研削と異なり光ファ イバ位置Oより後方において基部の大きい測定波形が 現われなかった。なお基部の出力開始点から最高出力

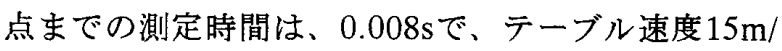
minより基部の長さ $2.0 \mathrm{~mm}$ と換算され、これは、研削 砥石の幾何的接触弦長さの二分の一である $1.99 \mathrm{~mm} に$ ほぼ一致している。これより不活性ガス雰囲気中での

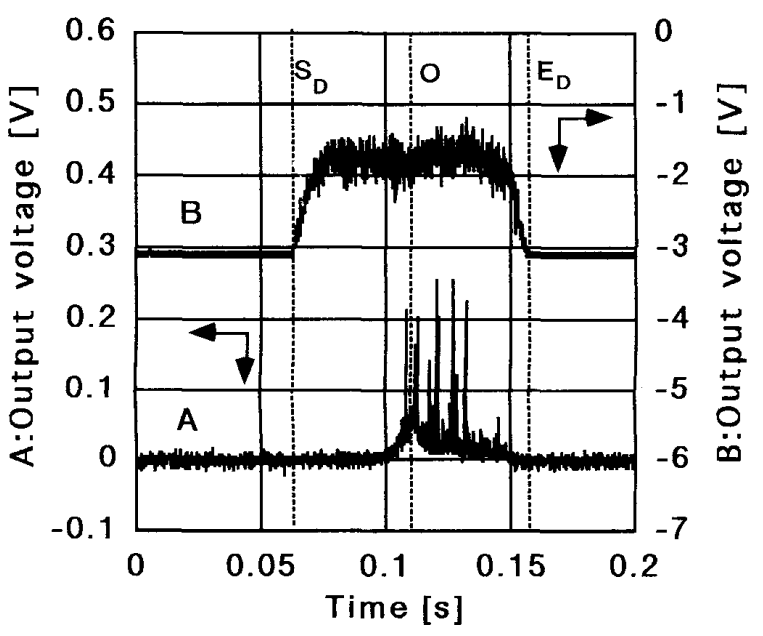

A:Measuring system B:Single point cutting system Grinding point
$S_{D}:$ Start point (Down cutting)
$\mathrm{O}$ : Optical fiber point
$E_{D}$ : End point (Down cutting)

\section{図9 S45C下向き削りの测定波形 (不活性ガス雾曲気)}

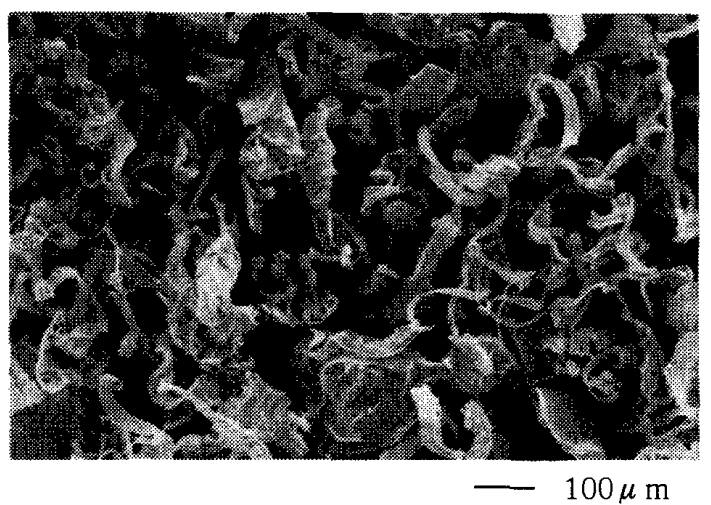

図10 S45Cの切屑（不活性ガス雾用気） 
測定波形基部は、砥石研削点の研削熱に対応した出力 と考える。また、一つのインパルスの出力時間はほぼ $10 \mu \mathrm{s}$ であり、砥石速度 $1500 \mathrm{~m} / \mathrm{min}$ 加ら長さ $250 \mu \mathrm{m}$ と 換算される。これは図10で見られる切屑塊の寸法100 $\sim 300 \mu \mathrm{m}$ に相当している。実際被加工物に作用する 砥粒の接触面積が、碈粒断面積より小さいことからも 同測定波形のインパルス部は、研削熱による切屑温度 に対応する出力と考察される。また図9において、測 定波形のピーク位置と動力計出力で示される光ファイ バ位置が一致していることで、一回転前の砥粒研削点 の研削熱の影響がないと確認された。このことは、砥 石表面温度が研削点通過後 1 回転する間に測定システ ムの適用範囲温度以下まで泠却されセンサの感知不能 な温度まで下がったものと考えられる。

図10の電顕(SEM)写真では、流机型切屑と破砕㧤 よび脱落砥粒が見られたのみで、図8のような空気雾 囲気中の切屑に見られた球状切屑は観察されなかっ た。このことは、砥石研削点の研削熱だけでは切屑を 溶融させるだけの温度に達し得なかったことがわか る。したがって、空気雾囲気中の測定波形（基部拉よ びインパルス部）には主にS45C切屑の研削熱以外の 熱すなわち二次的な切屑の酸化燃焼反応による発熱 が、広い簕囲で付加、影響しているものと考察され る。またこれは炭素含有量が、S45Cより少なく酸化 燃焼を起こしにくいと考えられるSUS304の測定波形 (図6(a))の結果加ら理解できる。ところで、雲团気 の異なる図6(b) と図9の二つの測定波形を同一時間軸 で重ね合わせると、光ファイバ位置O近傍においては 不活性ガス雾团気中の測定波形々空気雾囲気中の測定 波形の出力値は、同レベルで類似の波形を出力してい ることが確認される。すなわち、光ファイバ位置Oに おいて測定される測定波形は、砥粒切削開始直後の酸 化末反応状態にあるものと考えられ、雰囲気の影響 (酸化)を受けていないことが考えられる。光ファイバ 位置Oでの温度が、測定波形の温度変算より約 $500^{\circ} \mathrm{C}$ に達しており、青色酸化物 $\left(\mathrm{Fe}_{3} \mathrm{O}_{4}\right)$ が生じる約 $250^{\circ} \mathrm{C}$ に は十分な温度にもかかわらず不活性ガス雾囲気中の出

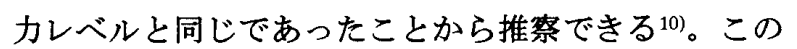
ように本実験条件において砥石研削点が光ファイバ位 置Oに位置する場合、空気中に怙ける測定波形も砥石 表面温度に対応した出力と考えられる。

\section{4. 結言}

砥石表面温度の測定波形を解析することにより以下 のことがわかった。

(1)本測定システムによる砥石表面温度の測定波形 は、本実験条件に括いて砥石研削点が光ファイバ位置 Oに位置する場合、雰囲気に影響されず表面温度に応 じた出力を示すことを確認した。

(2)この測定波形の基部は砥石表面温度を表し、イン パルス部は砥粒むしくは砥粒に付着した切屑の温度を 示し、それに対応した出力波形であることを確認し た。

(3)空気雾囲気中での測定波形は、特に被加工物材料 に含まれる炭素の影響を受け、研削熱と切居の酸化燃 焼反応による発熱が加味された波形を示す。

(4)光ファイバ位置O近傍を除き、波形注切屑の酸化 燃焼反応による出力である。研削熱以外の酸化燃焼反 応による発熱は、研削熱に比較してはるかに大きい熱 量を発生し無視できない。

\section{参考文献}

1)小野浩二:研削仕上,槙書店,(1972),121.

2)J.Peklenik:Ind.Anz.,1,3(1959),10.

3)W.E.Littmann and J.Wulff:Trans.ASME,47(1955),692.

4)上田隆司,細川晃,山本明:精密機械, $51,9(1985), 1732$.

5)磯部佳成,加藤泰生,香川正信:機論,60-570,C(1994),544.

6)河村末久,矢野章成,书口誠宏,杉田忠彰: 研削加工と䃌粒 加工,共立出版,(1988),26.

7)上田隆司,細川晃,山本明:精密機械,50,12(1984),1896.

8)(財日本規格協会編:JISハンドブック鉄鋼，財日本規格協 会,(1988).

9)I.O.Outwater and M.C.Shaw:Tans.ASME,74(1952),73. 10)H.H.ユーリック:腐食とその制御(第2版), 産業図書 (侏),(1974),185. 